\title{
Physical-chemical evaluation of groundwater quality in semi-arid areas: case study-Sabzevar plain, Iran
}

\author{
Ghasem Panahi ${ }^{1} \cdot$ Mahya Hassanzadeh Eskafi $^{1} \cdot$ Hamidreza Rahimi ${ }^{2,3}$ (D) $\cdot$ Alireza Faridhosseini ${ }^{1} \cdot$ Xiaonan Tang $^{4}$
}

Received: 28 April 2021 / Accepted: 30 September 2021 / Published online: 21 October 2021

(c) The Author(s) 2021

\begin{abstract}
Groundwater is one of the most important water sources in arid and semi-arid areas. With the increasing world population and the water demand for agriculture and urban use, the need for water resources has increased, especially in arid and semiarid regions, where groundwater resources play a significant role. To prevent the pollution of groundwater resources, various studies for their preservation and maintenance should be carried out, including a detailed plan for proper management of water resources and establishing a balance between water quality and how to use them. It becomes important to understand the spatial change of the quality of groundwater resources. In this study, Sabzevar plain, a typical region of semi-arid climate in Iran, was selected as a case study to assess the groundwater quality of the region, using data from 24 observation wells between 2015 and 2019. Using Arc GIS software, a map of groundwater quality parameters in the study area was prepared for quality assessment and comparison with existing international standards. The results showed that (except $\mathrm{pH}$ and $\mathrm{HCO}_{3}^{-}$) the concentration of Sodium, Magnesium, and other anions and cations is higher than the corresponding WHO standard limit, suggesting that the study area is unsuitable for drinking and agricultural use. According to the Wilcox chart, $87.5 \%$ of the samples are in the $\mathrm{C} 4 \mathrm{~S} 4$ class while $8.33 \%$ are in the C4S3 class, showing the groundwater unsuitable for agricultural use due to its high salinity and alkalinity. Piper diagrams show that more than $50 \%$ of the samples are non-carbonate alkalis, indicating a very high salinity in the area. According to the pie chart, chlorine ion and sodium ion are the dominant anions and cations in the Sabzevar plain, respectively. The Schuler diagram shows that none of the samples examined were in a good class for drinking. Therefore, considering the importance of water for agricultural activities in the study area, it is recommended to have agricultural management solutions to prevent groundwater mixing with freshwater resources.
\end{abstract}

Keywords Groundwater $\cdot$ Drinking water $\cdot$ Agriculture $\cdot$ Water quality $\cdot$ Sustainable water management

\section{Introduction}

Due to population growth in recent decades and climate changes caused by lack of rainfall and deduction of surface streams in arid and semi-arid regions, groundwater

Hamidreza Rahimi

Hamidreza.rahimi@liverpool.ac.uk

1 Department of Water Science and Engineering Faculty of Agriculture, Ferdowsi University of Mashhad, Mashhad, Iran

2 School of Engineering, University of Liverpool, 161 Brownlow Hill, Liverpool L693GH, UK

3 Yangtze Institute for Conservation and Development, Hohai University, Nanjing, China

4 Civil Engineering Department, Xi' an Jiaotong-Liverpool University, Suzhou, China has become the primary water source required for different purposes in these regions. Meanwhile, rapid population growth and increasing urbanization have caused significant changes in land usage, subsequently increasing demands for water consumption in various sectors such as agricultural, domestic and industrial activities (Kheirandish et al. 2020).

Considering the groundwater resources as the most reliable perennial source of freshwater (Lapworth et al. 2012), understanding and properly utilizing groundwater can lead to the sustainable development of social and economic activities in a region, especially in arid and semi-arid regions. In arid and semi-arid regions such as Iran and South Africa, about $85 \%$ and $70 \%$ of drinking water are from groundwater resources, respectively. Therefore, groundwater resources are an important part of the primary sources of water supply (Godfrey et al. 2019). Meanwhile, groundwater pollution in arid and semi-arid areas is a severe threat to drinking water 
supply, agriculture and industry in these regions (Basem et al. 2010). One of the most important factors in urban and agricultural development is the maintenance and improvement of surface water and groundwater resources. In this regard, Mansour-Bahmani et al. (2020) used intelligent models including multilayer perceptron (MLPNN) and genetic planning (GP) to predict daily urban wastewater discharge in Kerman. Their research results showed an acceptable accuracy of GP modeling. Haghiabi et al. (2018) predicted the qualitative components of the Tireh river located in southwestern Iran using artificial neural network (ANN), group method of data handling (GMDH), and support vector machine (SVM). Their results indicate that the ANN and SVM models perform well for predicting river water quality components.

Various factors can affect groundwater quality. Natural processes and human impacts are the most important factors in groundwater quality (Magesh et al. 2013). Future climate changes might increase the pressure on hydrological systems and the demand for water, which will reduce the groundwater quality. Thus, it is necessary to develop appropriate strategies to control the factors that reduce groundwater quality, especially in arid and semi-arid areas (Farid et al. 2019). Earthquakes and surface processes that interact with water might affect the quality of shallow groundwater (Babiker et al. 2007). One common method in environmental engineering studies is modeling the transfer of pollution in rivers. The use of numerical models is a good tool for managing water quality. In this regard, the research results by Parsaie and Haghiabi (2016) for River Severn in the U.K. showed that a good fit is obtained between observational data and analytical solution of the modified dispersion correction equation (MADE) model. Meshesha et al. (2021) used the SWAT model to simulate the groundwater quality of the Athabasca river basin, which showed that the use of the SWAT model for groundwater quality modeling has an effective role in the management of water resources.

Infiltration of saline water into groundwater resources of freshwater can cause major problems in agriculture, such as soil salinization, deduction of crop yield, and reduction of the area of arable land (Jeihouni et al. 2018). Accumulation of uncontrolled leachate at landfills also exacerbates groundwater pollution (Longe and Balogun 2010).

Based on the factors mentioned above, a comprehensive study of hydrogeochemistry is necessary to identify chemical processes affecting groundwater quality (Jeevanandam et al. 2007). One of the most practical methods for groundwater pollution management is monitoring and mapping (Hiscock et al. 1995). The results of a case study in the Xingguo region (Xie et al. 2015) showed that for the spatial characteristics of different regions, zoning is a method for better environmental management. Geostatistical methods provide the statistical characteristics of the measured data and have been become a practical and reliable tool for better management and conservation of water resources and development (Nas and Berktay 2010). The movement of aquifers between rocks, sediments and minerals can cause extensive changes in water quality. Therefore, rocks, sediments and minerals play an important role in changing groundwater quality (Stamatis et al. 2011). Jalees et al. (2021) assessed the quality of groundwater in Pakistan using hydrochemical modeling and found that a relationship exists between water quality factors and lithology and human activities.

Ahn and Chon (1999) investigated groundwater pollution and spatial relationships between groundwater quality parameters, topography, geology, land use and pollution sources. In their study, GIS (geographic information systems) was used to investigate the spatial relationship between groundwater quality parameters and pollution sources. In a study for groundwater quality mapping by Nas and Berktay (2010), it was reported that researchers such as Hudak (2001), Hudak and Sanmanee (2003) used Arc view GIS to map and analyze groundwater data.

Hiscock et al. (1995) assessed the groundwater vulnerability and showed that the GIS is appropriate for the information extraction and is flexible in revising the classification plan.

Mallick et al. (2018) assessed the quality of groundwater in the Aseer region of Saudi Arabia. Their research showed that geochemical modeling has an important role in identifying the effective factors of groundwater quality. Rostami et al. (2019) used geostatistical techniques to model the groundwater quality index in the Marand plain in Iran. Their research results showed that the parameters of land slope, groundwater level and transferability as input data play an important role in the best WQI estimation using the combined kriging method.

Due to the importance of water quality to different uses, the World Health Organization (WHO) has set different standards for different groundwater quality parameters. Therefore, the values of physical and chemical properties recommended by the WHO are an important base for assessing groundwater quality (Honarbakhsh et al. 2019).

As described above, although many studies have been undertaken to evaluate the groundwater quality, which plays an important role in water resources management, there is still a lack of study on the water resources quality assessment of plains in arid and semi-arid areas. In this study, Sabzevar was selected as a case study to represent a region with semiarid climate where groundwater quality plays a pivotal role for drinking and agriculture in the region. Furthermore, a hydrochemical study was taken to identify the chemical parameters affecting the groundwater quality, and GIS was used to generate groundwater quality maps for identifying the quality of selected points in the region. 


\section{Methodology}

\section{Study area}

The study area is Sabzevar city located at $36.2152^{\circ} \mathrm{N}$, $57.6678^{\circ} \mathrm{E}$, in the west of Khorasan Razavi province, Iran. Its area is $26.76 \mathrm{~km}^{2}$ with an average rainfall of $190 \mathrm{~mm}$ and an average temperature of $17^{\circ} \mathrm{C}$, and this area has a hot and dry climate. The Joghatai mountains are located in the north of the Sabzevar city, and the Mish mountains are located in the south of the city. In other words, Sabzevar city is surrounded by northern and southern heights. There are only two seasonal rivers called Kalshour in this region that lead the floods of Sabzevar plain to the desert salt marshes. Figure 1 shows the location of Sabzevar city in Khorasan Razavi province.

\section{Land use of Sabzevar basin}

Desertification can be related to salinity due to the overexploitation of groundwater resources. Mishra et al. (1994) conducted a study on desertification of a region in India in two periods of 11 years using the dataset of MSS, TM, and IRS-1 satellites, which showed that the area of salty regions had been increased significantly, from 0.75 to $6.19 \%$. Satellite datasets show a correlation between a decrease in groundwater level and an increase in saltiness. Figure 2 shows the land use map in Sabzevar basin. According to
Fig. 2, $958.13 \mathrm{~km}^{2}$ of the basin is allocated for agricultural lands, the largest area of which is in the groundwater aquifer of Sabzevar plain, so these agricultural lands have increased the drainage of the groundwater aquifer. Also, the groundwater level will be discussed later in the discussion, causing a sharp increase in salinity in the aquifer. The decline in groundwater level, discussed later in detail, causes an increase of saltiness in the aquifer.

\section{Sampling and analysis}

To evaluate the groundwater quality in the study area, data of 24 observational wells for a period from 2015 to 2019 were used for the study (Fig. 3).

The information of 24 observation wells in this study was sampled by Khorasan Razavi Regional Water Organization (www.khrw.ir). These wells were drilled from 1976 to 1991 and had a depth of 50-100 m. Most wells have a flow rate of less than 40 1/s. Figure 3 shows the location of the wells in this area. Based on the average monthly data collected, 11 physical and chemical parameters from 2015 to 2019 were studied and evaluated. Table 1 shows the parameters used in this study.

Standard methods for examining water and wastewater published by American Public Health Association (Association et al. 1915) were used to evaluate the samples for 11 physical and chemical parameters. A pH meter and an EC meter were used to measure the $\mathrm{pH}$ and the EC of the samples, respectively (Richards 1954). Heat method was used
Fig. 1 a Location of Khorasan Razavi province and Sabzevar city in Iran; b The river network in the basin

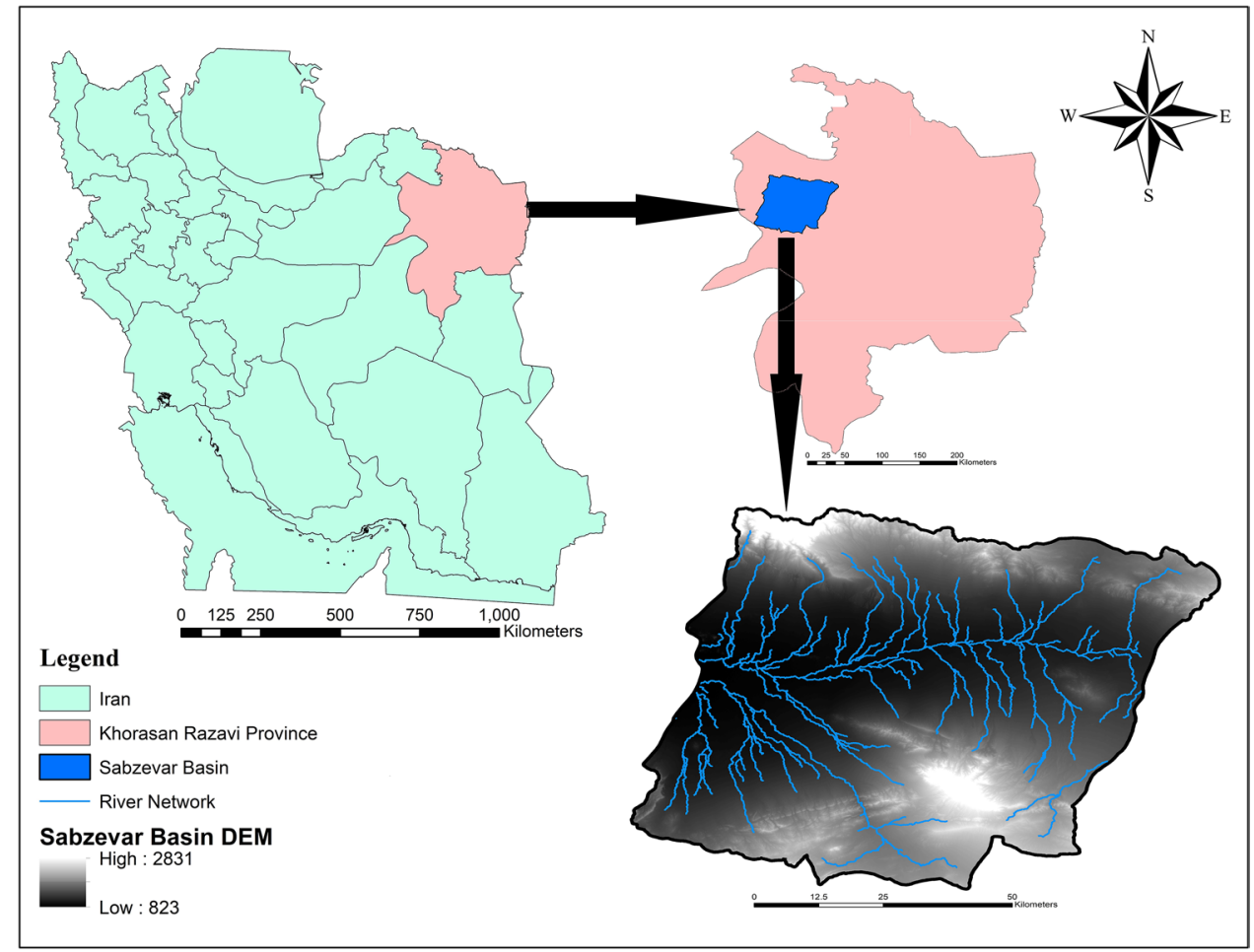


Fig. 2 Land use map in Sabzevar basin

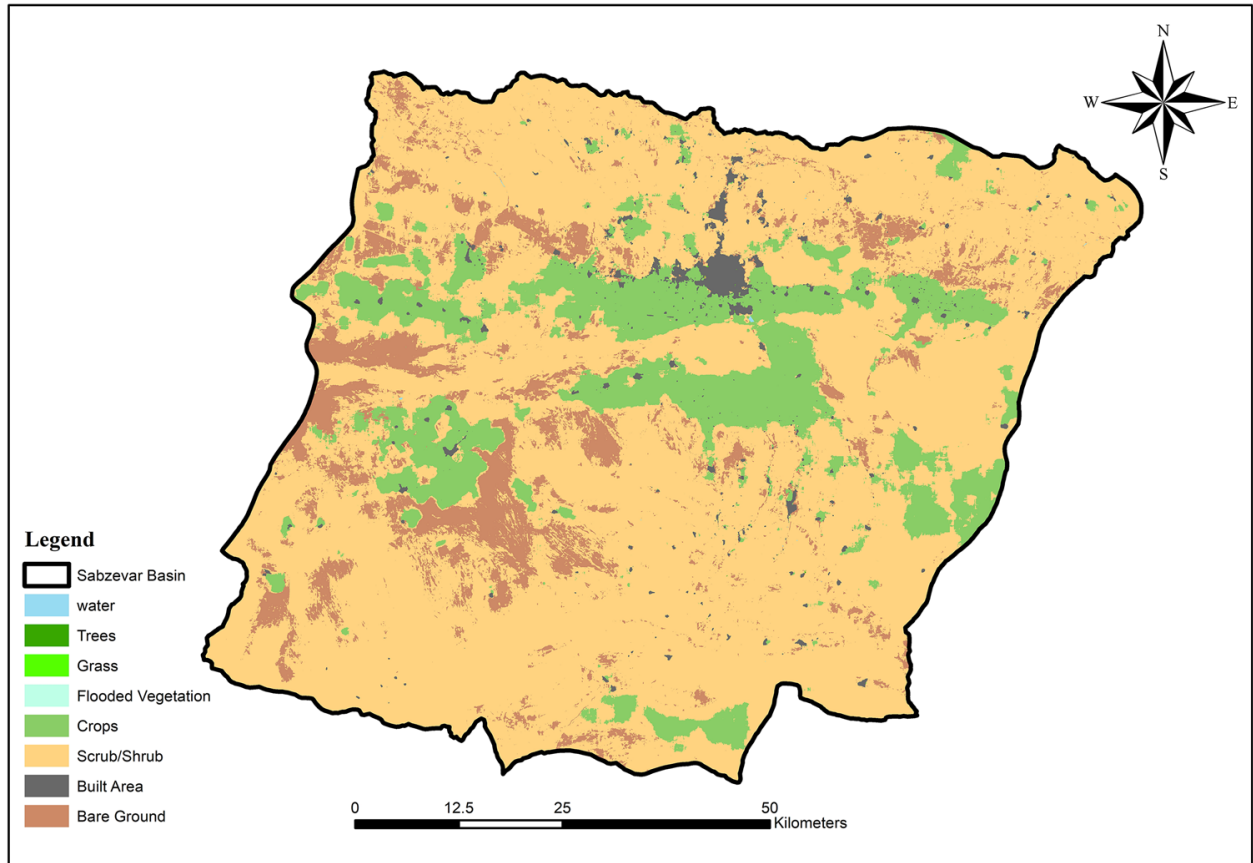

Fig. 3 Sabzevar aquifer and observational wells

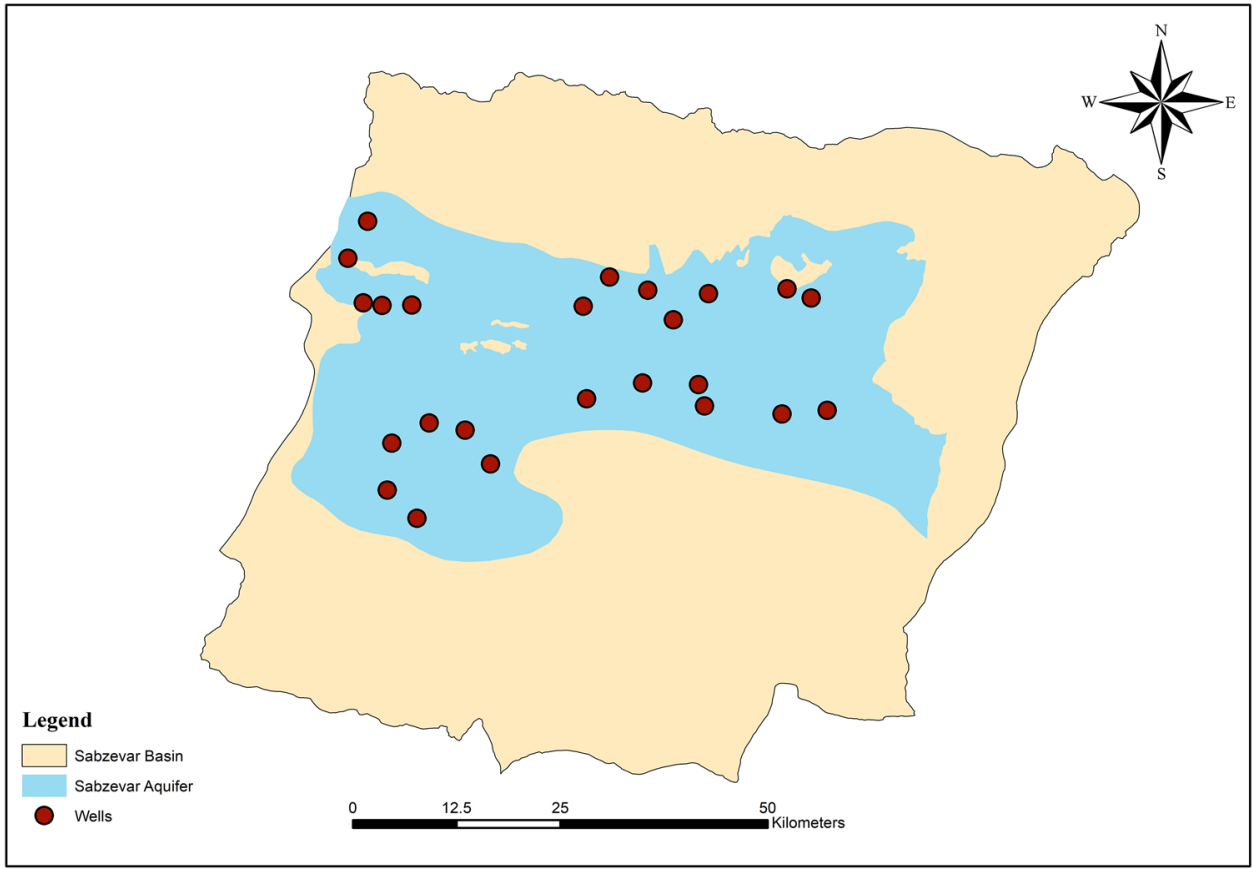

to measure the total dissolved solids. The amount of water was boiled in a porcelain dish, and the rest of the boiled water was then weighed and considered as TDS (Association et al. 1915). To measure chloride in a water sample, silver nitrate was used based on the amount of silver nitrate. Flow photometer was used to measure sodium and potassium ions (Osborn and Johns 1951). EDTA titration was used to measure calcium and magnesium ions (Richards 1954) as well as bicarbonate, where titration was performed using sulfuric acid. The amount of Sulfate was also measured using a spectrophotometer. According to Eq. (1), $\mathrm{Ca}^{2+}$ (meq/L) and $\mathrm{Mg}^{2+}(\mathrm{meq} / \mathrm{L})$ were used to calculate the total hardness (TH) (Boyd 2019):

$\mathrm{TH}\left(\mathrm{mg}\right.$ of $\left.\mathrm{CaCO}_{3}\right)=\left(\mathrm{Ca}^{2+}+\mathrm{Mg}^{2+}\right) \times 50$.

The behavior of some ions studied includes $\mathrm{Ca}^{2+}$, $\mathrm{Mg}^{2+}, \mathrm{Na}^{+}, \mathrm{K}^{+}, \mathrm{Cl}^{-}, \mathrm{HCO}_{3}{ }^{-}$and $\mathrm{SO}_{4}{ }^{2-}$, while some 
Table 1 Characteristics used in this research

\begin{tabular}{ll}
\hline Characteristics & Definition \\
\hline $\mathrm{TDS}$ & Total dissolved solids \\
$\mathrm{TH}$ & Total hardness \\
$\mathrm{EC}$ & Electrical conductivity \\
$\mathrm{pH}$ & Power of hydrogen \\
$\mathrm{Ca}^{2+}$ & Calcium ion \\
$\mathrm{Mg}^{2+}$ & Magnesium ion \\
$\mathrm{Na}^{+}$ & Sodium \\
$\mathrm{K}^{+}$ & Potassium \\
$\mathrm{Cl}^{-}$ & Chloride \\
$\mathrm{HCO}_{3}{ }^{-}$ & Bicarbonate \\
$\mathrm{SO}_{4}{ }^{2-}$ & Sulfate \\
\hline
\end{tabular}

physicochemical properties such as EC, TDS and pH were selected and evaluated for drinking and agricultural purposes. The World Health Organization (WHO) has provided standards for the maximum allowable values of each water quality parameter. In the present study, a comparison was made between the studied parameters and the standard values reported by the WHO (Cotruvo 2017). Pie, Schuler, Piper and Wilcox diagrams were drawn to evaluate the groundwater quality parameters for agricultural and drinking purposes.

Statistics software-SPSS Version 22 was used to statistically analyze the qualitative data of groundwater for observation wells in Sabzevar region and to find the correlation matrix. AqQA software was used to conduct the hydrochemical analyses for groundwater quality data. Based on the results obtained from the statistical and hydrochemical analyses, the spatial distribution of each studied characteristic was plotted by the ordinary kriging method using Arc GIS 10.4.1 software.

\section{Groundwater level fluctuations in Sabzevar plain}

Based on the monthly measurements of groundwater level, the hydrograph of Sabzevar plain from 1978 to 2020 has been drawn by the Thiessen method for an alluvial zone with an area of $1726 \mathrm{~km}^{2}$ (Fig. 4). The results show an average annual drop of $37 \mathrm{~cm}$ in groundwater level. The plotted hydrograph (Fig. 4) shows that the aquifer groundwater level declines and has fallen sharply in recent years.

Geophysical studies in Sabzevar plain include 286 electrical soundings with a length of AB1000 to $2000 \mathrm{~m}$. Six exploratory wells was also drilled. The exploratory studies included the bottom rock and its changes, aquifer thickness and hydrodynamic coefficients. The bedrock of the eastern parts is mainly made of igneous rocks and in most of the plain is Neogene gypsum and evaporative salt sediments.

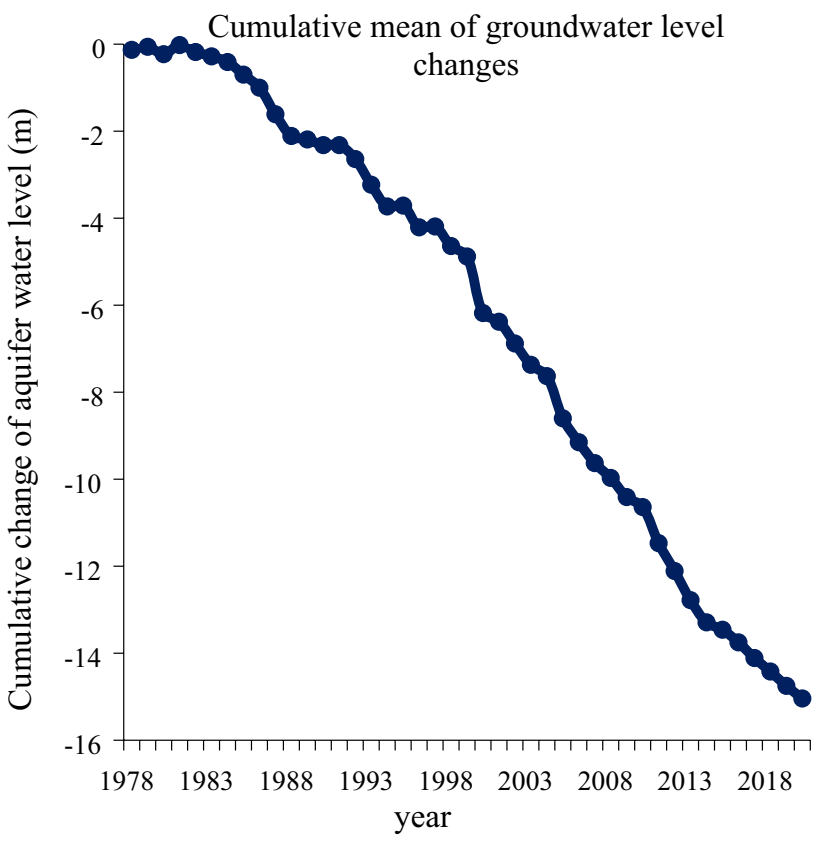

Fig. 4 The hydrograph of Sabzevar plain from 1978 to 2020

This bedrock is folded and protrudes in some parts of the plain center. The thickness of the alluvium reaches almost $300 \mathrm{~m}$ in the northwest of the plain, while it is less than $50 \mathrm{~m}$ in the central and southern areas, and only in the southeastern part, the aquifer is relatively suitable. The hydrodynamic coefficients of the aquifer in Sabzevar plain were obtained by testing the pumping of exploratory wells and the geophysical RT map. The coefficient of transferability varies from a minimum of $85 \mathrm{~m}^{2} /$ day in the central area to a maximum of $3000 \mathrm{~m}^{2} /$ day in the northwest alluvial fan of the plain, and the average storage coefficient is 5\% (Maghfouri et al. 2017).

Figure 5 indicates the fluctuation of groundwater level in the basin of Sabzevar. After entering the data into the GIS using satellite images of the geological site (https://earthexplo rer.usgs.gov), and creating a DEM map of the study area using the kriging method, a groundwater potential level map was obtained. The groundwater level of the eastern regions in the Sabzevar basin is different from that in the central and western regions. Therefore, the groundwater level in the eastern and southeastern regions is higher than that in the central areas. The reason for this rise can be related to agricultural lands and the discharge of agricultural and urban wastewater to these areas, as shown in Fig. 5, where the general direction of groundwater flow in this basin is from east to west.

\section{Geology of the region}

Aquifer's physical condition, bed mineralogy and climatic conditions are influenced by various factors such as rock weathering, vegetation. Figure 6 shows the geological map 
Fig. 5 Groundwater level in the basin of Sabzevar

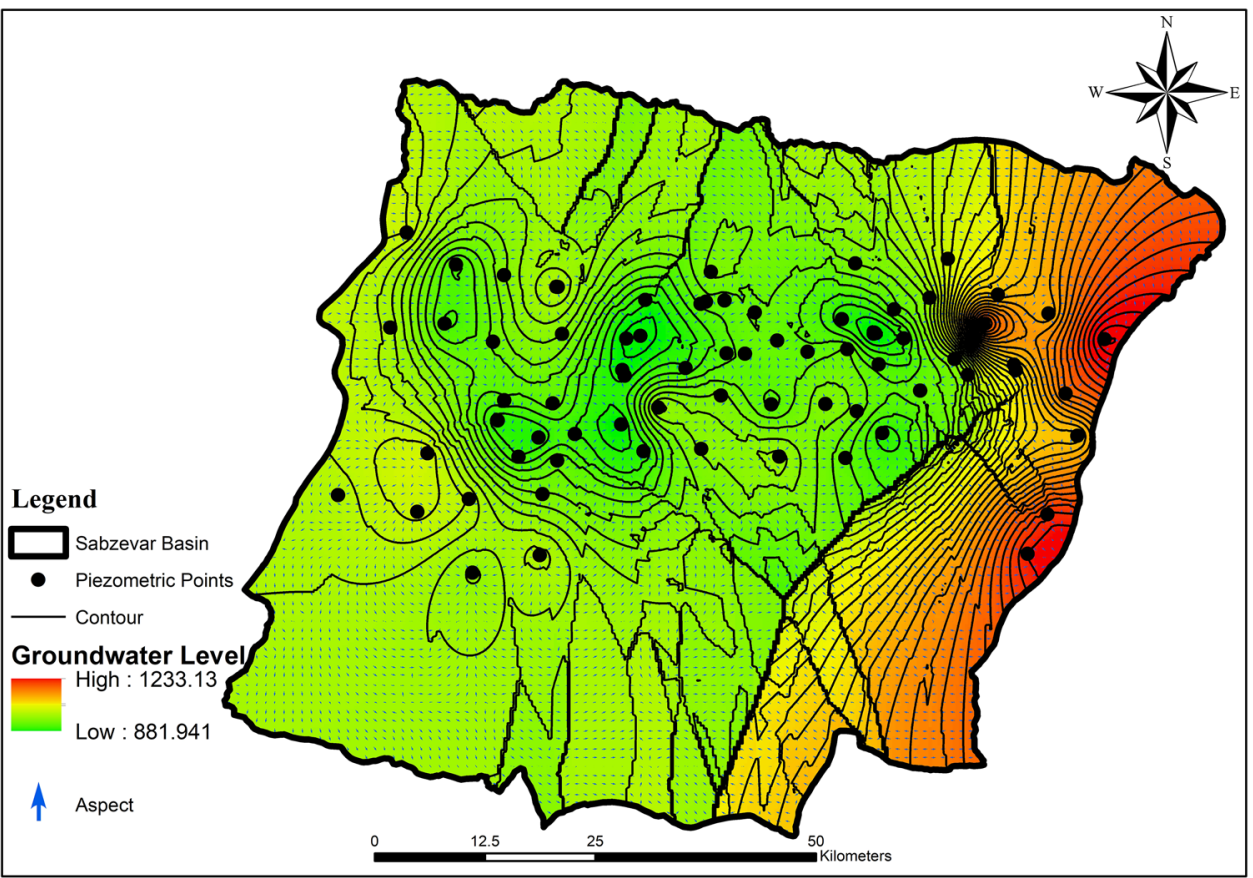

of Sabzevar basin. Sabzevar basin is geologically composed of ultrabasic to basaltic and semi-acidic igneous rocks of the upper cretaceous. The northern elevations of this basin are composed of harzburgite and dunite, while the southern elevations of the region are composed of andesite, tuff, diabase and granite. These igneous rocks, along with calcareous sediments, have disintegrated at different times under the influence of tectonic forces and formed colored mixtures. Also, a series of flysch sediments and destructive and evaporitic rocks have been widely developed in the southeastern areas of the basin. During the Neogene, a series of marls and gypsum marls and conglomerates with marl layers in the southeast of the basin were formed. The names of the stones in Sabzevar basin are shown in Table 2.

\section{Results}

\section{Groundwater description}

Table 3 shows the statistical analysis results for 11 studied characteristics and the maximum allowable limit for each of them, presented by the World Health Organization (Cotruvo 2017). The average TDS for Sabzevar plain is $4155 \mathrm{mg} / \mathrm{L}$, showing that the groundwater is unsuitable for drinking (Cotruvo 2017). Water hardness (TH), caused by the accumulation of salts due to the contact with geological formations (Patil and Patil 2011), is between 197 and $2846 \mathrm{mg} / \mathrm{L}$ with an average of $1077.5 \mathrm{mg} / \mathrm{L}$, which is considered higher than the limit recommended by the WHO (Cotruvo 2017). The value of electrical conductivity is from 1812.4 to $12071.3 \mu \mathrm{S} / \mathrm{cm}$ with an average of 6596.6 $\mu \mathrm{S} / \mathrm{cm}$, which is much higher than the allowable limit.

The analysis results show the range of $\mathrm{pH}$ changes, defined as the balance between the concentration of hydrogen ions and hydroxyl ions (Prasanth et al. 2012), is between 7.63 and 8.65 with an average of 8.05 . Calcium concentration is $21.2-711.7 \mathrm{mg} / \mathrm{L}$ with an average of 230.4. According to Table 2, Magnesium concentration is between 29.72 and $711.7 \mathrm{mg} / \mathrm{L}$ with an average of $120.3 \mathrm{mg} / \mathrm{L}$. Sodium concentration is 323.8 to $1966 \mathrm{mg} / \mathrm{L}$ with an average of 1003 , from which groundwater is unsuitable for drinking (Cotruvo, 2017). The concentration of Chlorine, which is mainly sourced by the discharge of industrial wastewater, is between 320.92 and $3513.8 \mathrm{mg} / \mathrm{L}$ with an average of 1669.4, which is more than the allowable limit recommended by the standard (Cotruvo 2017). Bicarbonate concentration is $64.76-495.3 \mathrm{mg} / \mathrm{L}$ with an average of 197, which is lower than the limit recommended by Cotruvo (2017).

Furthermore, according to Table 3, the amount of Sulfate that increases as a result of discharge of industrial and 


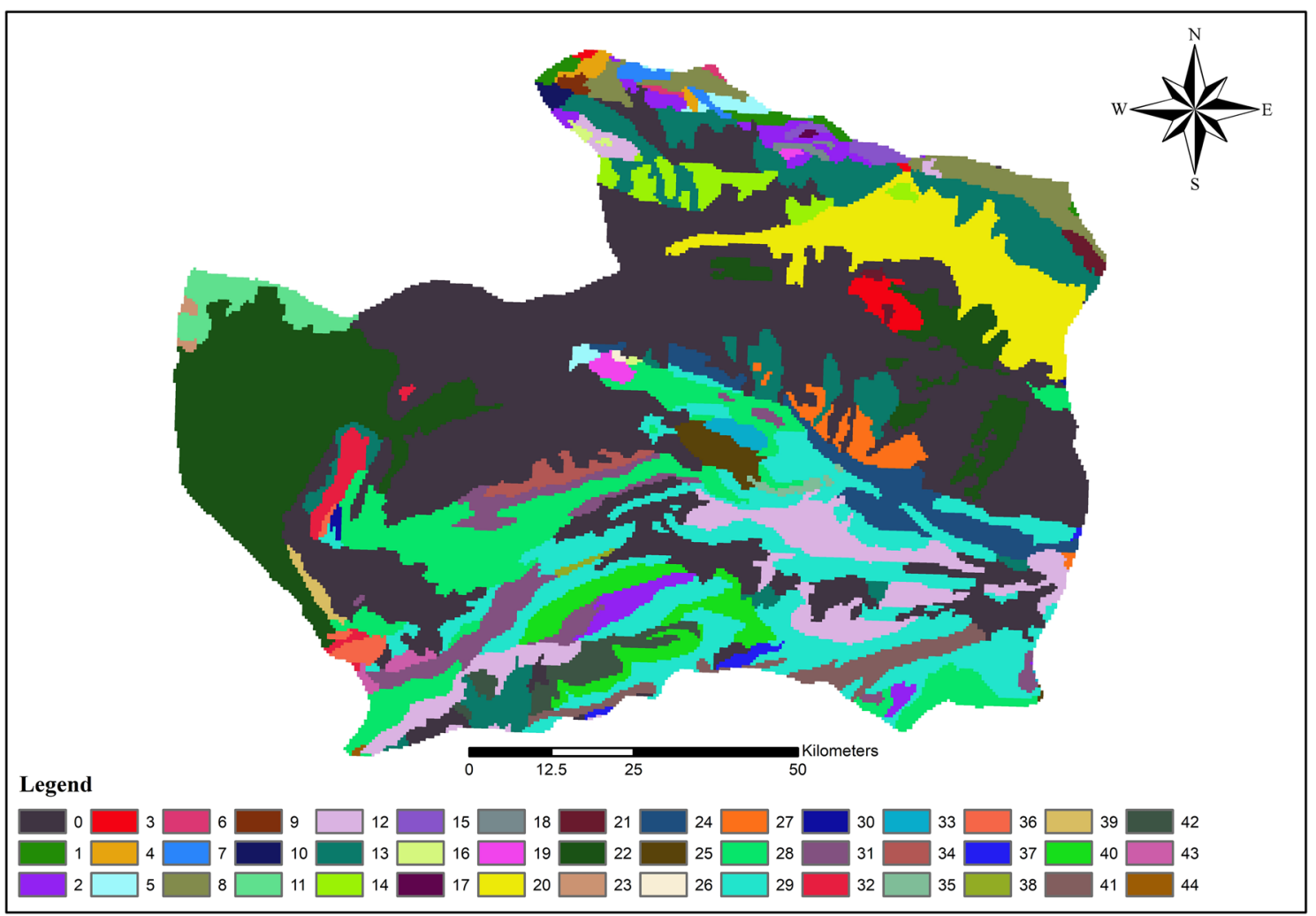

Fig. 6 Geological map in the basin of Sabzevar

domestic wastewater (Patil and Patil 2011), is between 219 and $1449 \mathrm{mg} / \mathrm{L}$ with an average of $850 \mathrm{mg} / \mathrm{L}$, which is beyond the value recommended by Cotruvo (2017).

To measure the relationship between groundwater quality variables, the correlation coefficient, which is the interaction of two variables (Patil and Patil 2011), was calculated for Sabzevar area (Table 4). The highest positive correlations are between TDS and $\mathrm{Cl}(R=0.991), \mathrm{K}$ and $\mathrm{Cl}(R=0.967)$, and Magnesium and electrical conductivity $(R=0.863)$, respectively, which is in line with a study done by Magesh et al. (2013): The electrical conductivity and total hardness are controlled by the ions of Magnesium, Sodium, Calcium, Sulfate, and Potassium, and caused by the interaction and dissolution of natural processes such as rock-water. The results also showed that there is a strong significant positive correlation between $\mathrm{SO}_{4}$ and $\mathrm{EC}, \mathrm{Mg}$ and $\mathrm{Na}$. It can also be stated that $\mathrm{HCO}_{3}$ has a significant positive correlation with $\mathrm{pH}$ with a Pearson coefficient of 0.899 , indicating that the carbonate content plays an important role in controlling the $\mathrm{pH}$ of water (Magesh et al. 2013). As shown in Table 4, TDS has a strong and significant positive correlation with Calcium, Magnesium, Sodium, Potassium, Chlorine and TH, which is consistent with the results by Patil and Patil (2011).

The pie chart of different parameters is shown in Fig. 7, which reveals that $\mathrm{Cl}^{-}$is a dominant anion because of $\mathrm{Cl}^{-}$
$>\mathrm{SO}_{4}^{2->} \mathrm{HCO}_{3}^{-}(\mathrm{mg} / \mathrm{L})$ and that $\mathrm{Na}^{+}$is a dominant cation based on $\mathrm{Na}^{+>} \mathrm{Mg}^{2+>} \mathrm{Ca}^{2+>} \mathrm{K}^{+}(\mathrm{mg} / \mathrm{L})$.

Based on the Schuler diagram shown in Fig. 8, none of the samples tested were suitable for drinking, because $62.5 \%$ $\mathrm{SO}_{4}^{2-}, 33.33 \% \mathrm{TH}, 33.33 \% \mathrm{Cl}^{-}, 50 \% \mathrm{Na}^{+}$and $45.83 \%$ TDS in the results are over the limits. Higher TDS values are due to the longer time when groundwater is associated with the body of the aquifer and the presence of its salts (Selvam et al. 2013).

Piper diagram was introduced to describe water chemistry by Hill (1940) and Piper (1944). The Piper diagram applied in this study area is represented in Fig. 9, which shows the chemical properties of water based on the relative concentration of the constituent substance to the total solution. This rhombus-shaped complex is located in region 7 , which means that non-carbonate alkali is more than $50 \%$ and is different from other alkalis and that strong acids are superior, indicating very high salinity of water. In this diagram, the right triangle shows the anions, and based on the data density, the strong acids are more than the weak acids, which are located in region 4 . The left triangle represents the cations, the data densities show region 2 , where the alkali is higher than the earth alkaline. The combination of the two 
Table 2 The complete names of the stones in Sabzevar area

\begin{tabular}{|c|c|c|c|}
\hline No & Description & No & Description \\
\hline 0 & Low-level piedmont fan and valley terrace deposits & 23 & $\begin{array}{l}\text { Light-red to brown marl and gypsiferous marl with sandstone } \\
\text { intercalations }\end{array}$ \\
\hline 1 & Harzburgite & 24 & Conglomerate and sandstone \\
\hline 2 & $\begin{array}{l}\text { Tectonic melange_-association of ophiolitic components, pelagic } \\
\text { limestone, radiolarian chert, and shale with or without Eocene } \\
\text { sedimentary rocks (Colored Melange complex) }\end{array}$ & 25 & Gabbro to diorite, diorite and trondhjemite \\
\hline 3 & Andesitic to basaltic volcanic tuff & 26 & Nummulitic limestone \\
\hline 4 & Dacitic andesitic volcanic tuff & 27 & $\begin{array}{l}\text { Red and green silty, gypsiferous marl, sandstone and gypsum } \\
\text { (Lower Red FM) }\end{array}$ \\
\hline 5 & $\begin{array}{l}\text { Submarine, vesicular basalt, locally with pillow structure in asso- } \\
\text { ciation with radiolarian chert }\end{array}$ & 28 & Andesitic and basaltic volcanic rocks \\
\hline 6 & Radiolarian chert and shale & 29 & $\begin{array}{l}\text { Eocene flysch in general, composed of shale, marl, sandstone, } \\
\text { conglomerate and limestone }\end{array}$ \\
\hline 7 & $\begin{array}{l}\text { Pelagic limestone, radiolarian chert and shale in association with } \\
\text { basalt and basaltic andesite pillow lava }\end{array}$ & 30 & Andesitic volcanics \\
\hline 8 & Serpentinite & 31 & Globotrunca limestone \\
\hline 9 & Basaltic volcanic rocks & 32 & $\begin{array}{l}\text { Thick bedded to massive, white to pinkish orbitolina-bearing } \\
\text { limestone (TIZKUH FM) }\end{array}$ \\
\hline 10 & Spilitic rocks locally with pillow structure & 33 & Granite \\
\hline 11 & Salt flat & 34 & Limestone, marl and sandstone \\
\hline 12 & Polymictic conglomerate and sandstone & 35 & $\begin{array}{l}\text { Red sandstone and shale with subordinate sandy limestone } \\
\text { (DORUD FM) }\end{array}$ \\
\hline 13 & High-level piedmont fan and valley terrace deposits & 36 & Albian-Cenomanian marl and argillaceous limestone \\
\hline 14 & Gypsiferous marl & 37 & Marl, gypsiferous marl and limestone \\
\hline 15 & Diabase & 38 & Nummulitic limestone \\
\hline 16 & Rhyolitic to rhyodacitic subvolcanic & 39 & Stream channel, braided channel and flood plain deposits \\
\hline 17 & Layered and isotropic gabbro & 40 & Red conglomerate and sandstone \\
\hline 18 & Diorite & 41 & Conglomerate and sandstone \\
\hline 19 & Granite to diorite & 42 & Marl, shale, sandstone and conglomerate \\
\hline 20 & Clay flat & 43 & Pale-red, polygenic conglomerate and sandstone \\
\hline 21 & Sandstone, calcareous sandstone and limestone & 44 & Fluvial conglomerate, Piedmont conglomerate and sandstone \\
\hline 22 & Unconsolidated windblown sand deposit including sand dunes & & \\
\hline
\end{tabular}

Table 3 Statistical analysis of the studied parameters of Sabzevar groundwater (2015-2019)

\begin{tabular}{lllllccl}
\hline Characteristic & Unit & Minimum & Maximum & Mean & Std. deviation & $\begin{array}{l}\text { Coefficient } \\
\text { variation }\end{array}$ & WHO (2017) \\
\hline $\mathrm{TDS}$ & $\mathrm{mg} / \mathrm{L}$ & 1141.8 & 7604.9 & 4155.9 & 2041.9 & 49.13 & 1000 \\
$\mathrm{TH}$ & $\mathrm{mg} / \mathrm{L}$ & 197 & 2848.67 & 1077.5 & 795.3 & 73.809 & 500 \\
$\mathrm{EC}$ & $\mu \mathrm{S} / \mathrm{cm}$ & 1812.4 & $12,071.3$ & 6596.6 & 3241.1 & 49.13 & 1500 \\
$\mathrm{pH}$ & - & 7.63 & 8.65 & 8.049 & 0.268 & 3.32 & $7.5-8.5$ \\
$\mathrm{Ca}^{2+}$ & $\mathrm{mg} / \mathrm{L}$ & 21.2 & 711.7 & 230.4 & 205.6 & 89.21 & 75 \\
$\mathrm{Mg}^{2+}$ & $\mathrm{mg} / \mathrm{L}$ & 29.72 & 358.6 & 120.3 & 90.08 & 74.85 & 30 \\
$\mathrm{Na}^{+}$ & $\mathrm{mg} / \mathrm{L}$ & 323.8 & 1966 & 1003 & 396.9 & 39.59 & 200 \\
$\mathrm{~K}^{+}$ & $\mathrm{mg} / \mathrm{L}$ & 0 & 256.1 & 79.39 & 85.33 & 107.5 & 12 \\
$\mathrm{Cl}^{-}$ & $\mathrm{mg} / \mathrm{L}$ & 320.92 & 3513.8 & 1669.4 & 1038.3 & 62.19 & 200 \\
$\mathrm{HCO}_{3}^{-}$ & $\mathrm{mg} / \mathrm{L}$ & 64.76 & 495.3 & 197 & 112.4 & 57.06 & 300 \\
$\mathrm{SO}_{4}{ }^{2-}$ & $\mathrm{mg} / \mathrm{L}$ & 219.8 & 1449 & 850.8 & 327.5 & 38.48 & 200 \\
\hline
\end{tabular}


Table 4 Pearson correlation coefficient between different groundwater quality parameters (2015-2019)

\begin{tabular}{|c|c|c|c|c|c|c|c|c|c|c|c|}
\hline & $\mathrm{EC}$ & TDS & $\mathrm{pH}$ & $\mathrm{Ca}^{2+}$ & $\mathrm{Mg}^{2+}$ & $\mathrm{Na}^{+}$ & $\mathrm{K}^{+}$ & $\mathrm{HCO}_{3}^{-}$ & $\mathrm{Cl}^{-1}$ & $\mathrm{SO}_{4}{ }^{2-}$ & $\mathrm{TH}$ \\
\hline $\mathrm{EC}$ & 1 & & & & & & & & & & \\
\hline TDS & $1.000 * *$ & 1 & & & & & & & & & \\
\hline $\mathrm{pH}$ & $-0.643 * *$ & $-0.643 * *$ & 1 & & & & & & & & \\
\hline $\mathrm{Ca}^{2+}$ & $0.819 * *$ & $0.819 * *$ & $-0.814^{* *}$ & 1 & & & & & & & \\
\hline $\mathrm{Mg}^{2+}$ & $0.863 * *$ & $0.863 * *$ & $-0.422 *$ & $0.590 * *$ & 1 & & & & & & \\
\hline $\mathrm{Na}^{+}$ & $0.943 * *$ & $0.943 * *$ & $-0.505^{*}$ & $0.639 * *$ & $0.760 * *$ & 1 & & & & & \\
\hline $\mathrm{K}^{+}$ & $0.961 * *$ & $0.961 * *$ & $-0.628 * *$ & $0.805^{* *}$ & $0.856^{* *}$ & $0.877 * *$ & 1 & & & & \\
\hline $\mathrm{HCO}_{3}^{-}$ & $-0.542 * *$ & $-0.542 * *$ & $0.899 * *$ & $-0.656^{* *}$ & -0.325 & $-0.464 *$ & $-0.531 * *$ & 1 & & & \\
\hline $\mathrm{Cl}^{-}$ & $0.991 * *$ & $0.991 * *$ & $-0.704 * *$ & $0.841 * *$ & $0.853 * *$ & $0.921 * *$ & $0.967 * *$ & $-0.595^{* *}$ & 1 & & \\
\hline $\mathrm{SO}_{4}{ }^{2-}$ & $0.812^{* *}$ & $0.812^{* *}$ & -0.385 & $0.581^{* *}$ & $0.689^{* *}$ & $0.826^{* *}$ & $0.728^{* *}$ & -0.397 & $0.740 * *$ & 1 & \\
\hline $\mathrm{TH}$ & $0.916^{* *}$ & $0.916^{* *}$ & $-0.764 * *$ & $0.963 * *$ & $0.786^{* *}$ & $0.744 * *$ & $0.903 * *$ & $-0.611 * *$ & $0.929 * *$ & $0.676^{* *}$ & 1 \\
\hline
\end{tabular}

*Denotes significant differences at $95 \%$ level

right and left triangles, which shows the total community of water, is located in the upper rhombus.

Figure 10 shows the Wilcox diagram for groundwater samples from wells in the Sabzevar plain. Figure 10 reveals that $4.17 \%$ of the groundwater samples are in C3S3 class with moderate salinity and alkalinity. Furthermore, $8.33 \%$ of the samples are in C4S3 class and $87.5 \%$ are in C4S4 class, which have a lot of salinity and alkalinity for agricultural use.

Figure 11 shows the distribution of each studied quality parameter in the groundwater of Sabzevar plain. In each map, the distribution of each groundwater quality parameter in Sabzevar city was examined.

As seen in Fig. 11a, the highest values of solid particles (TDS) in the water are located in the middle part of this plain, while the lowest values of TDS are located in the western part of the plain. The TDS has an average of $4155.9 \mathrm{mg} / \mathrm{L}$ with a standard deviation of $2041.9 \mathrm{mg} / \mathrm{L}$ (Table 3). Since the standard of TDS given by the WHO (2017) is $1000 \mathrm{mg} / \mathrm{L}$, the amount of TDS in the groundwater of this plain is twice its allowable limit.

Another parameter investigated is the total hardness (TH) shown in Fig. 11b. The higher values of $\mathrm{TH}$ are seen in the central and southern regions of this plain, whereas the lower values are seen in the western and northern regions. The average TH of groundwater in this plain is $1077.5 \mathrm{mg} / \mathrm{L}$ with a standard deviation of $795.3 \mathrm{mg} / \mathrm{L}$. According to the allowable limit $500 \mathrm{mg} / \mathrm{L}$ of TH for drinking water by the WHO, the water in the study region is not suitable for drinking. Dissolution of formations with saline and gypsum in Sabzevar plain has increased salinity, TDS and TH.

Figure 11c reveals that the higher values of electrical conductivity (EC) are in the central area whereas the lower values are in the western parts of the plain. The average of $\mathrm{EC}$ is $6596.6 \mu \mathrm{S} / \mathrm{cm}$ with a standard deviation of $3241.1 \mu \mathrm{S} /$ $\mathrm{cm}$. According to the standard value $(1500 \mu \mathrm{S} / \mathrm{cm})$ for the

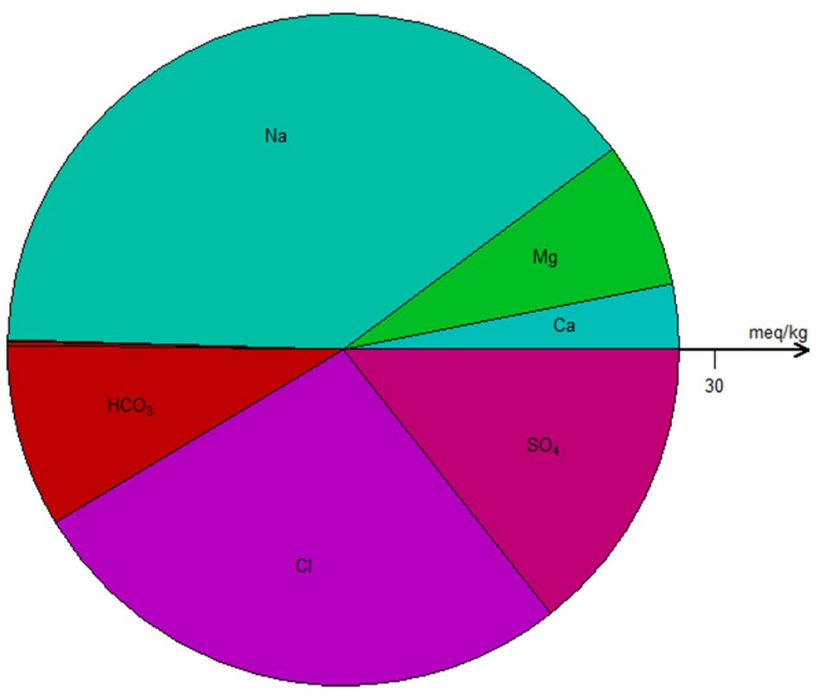

Fig. 7 Pie chart for different groundwater quality parameters

electrical conductivity of drinking water provided by the WHO (2017), the average EC of groundwater in this plain is much higher than the allowed limit, hence suggesting the groundwater is not suitable for drinking. The electrical conductivity (EC) of groundwater increases with a raise in amounts of Sulfate, Chloride, Sodium, Potassium, Calcium and Magnesium. Due to the rising of bedrock in the southern part, the EC of groundwater in this region is much more than in the northern areas.

The maximum $\mathrm{pH}$ values are located in the northern to northwestern regions of the Sabzevar plain and its minimum values are in the central, southern and parts of the southeastern regions (Fig. 11d). Geological and biological factors can have some effects on $\mathrm{pH}$ of groundwater (Qishlaqi et al. 2017) that the average of $\mathrm{pH}$ in this area is 8.049 with a standard deviation of 0.268 , which indicates that the 
Fig. 8 Schuler diagram of different groundwater quality parameters
Fig. 9 Piper diagram of different groundwater quality parameters

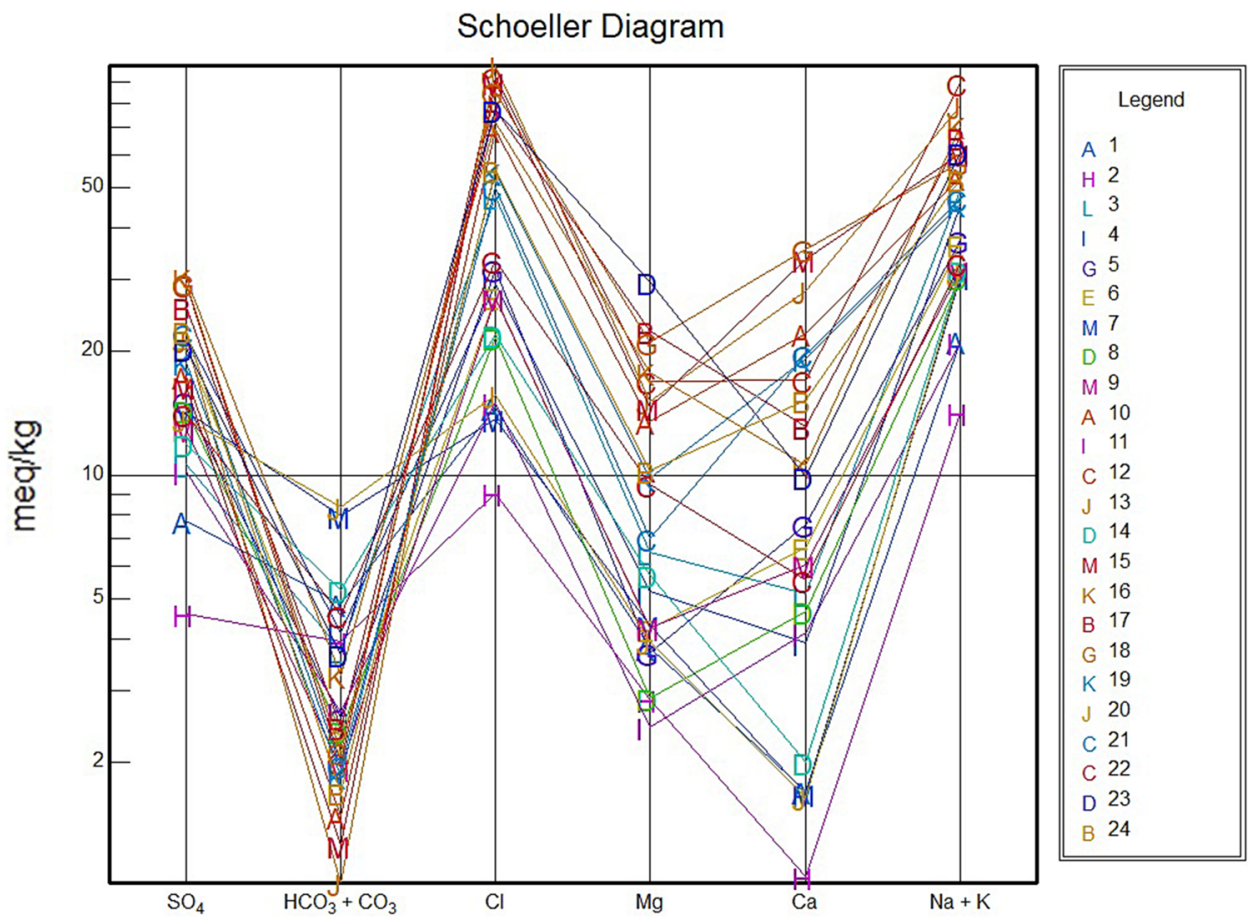

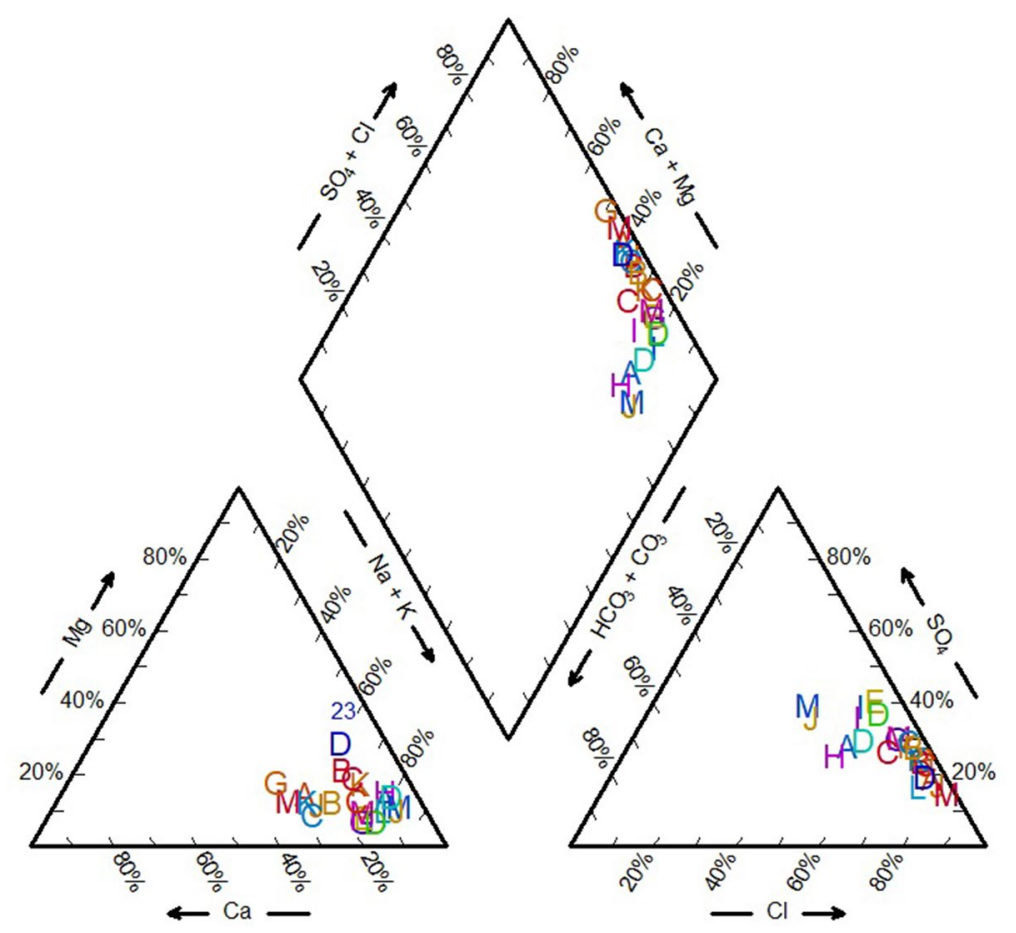

samples studied in this study are alkaline. The WHO (2017) suggests a maximum limit of 7.5-8.5 for this parameter, so the groundwater in Sabzevar plain is suitable in terms of $\mathrm{pH}$, because its average of $\mathrm{pH}$ is within the suggested range.

Calcium $(\mathrm{Ca})$ is another ion which was studied in this study. Figure 11e shows that the higher concentration of calcium is in the central and southern regions whilst the lower amount of calcium is located in the northern and western regions. The average concentration of Calcium in the groundwater of this plain is $230.4 \mathrm{mg} / \mathrm{L}$ with a standard deviation of $205.6 \mathrm{mg} / \mathrm{L}$. The WHO (2017) stated that $75 \mathrm{mg} / \mathrm{L}$ is the allowable limit for calcium. Therefore, the concentration of Calcium in the groundwater of Sabzevar plain is very high. The high concentration of this ion in this 
Fig. 10 Wilcox diagram for groundwater samples of wells in the Sabzevar plain

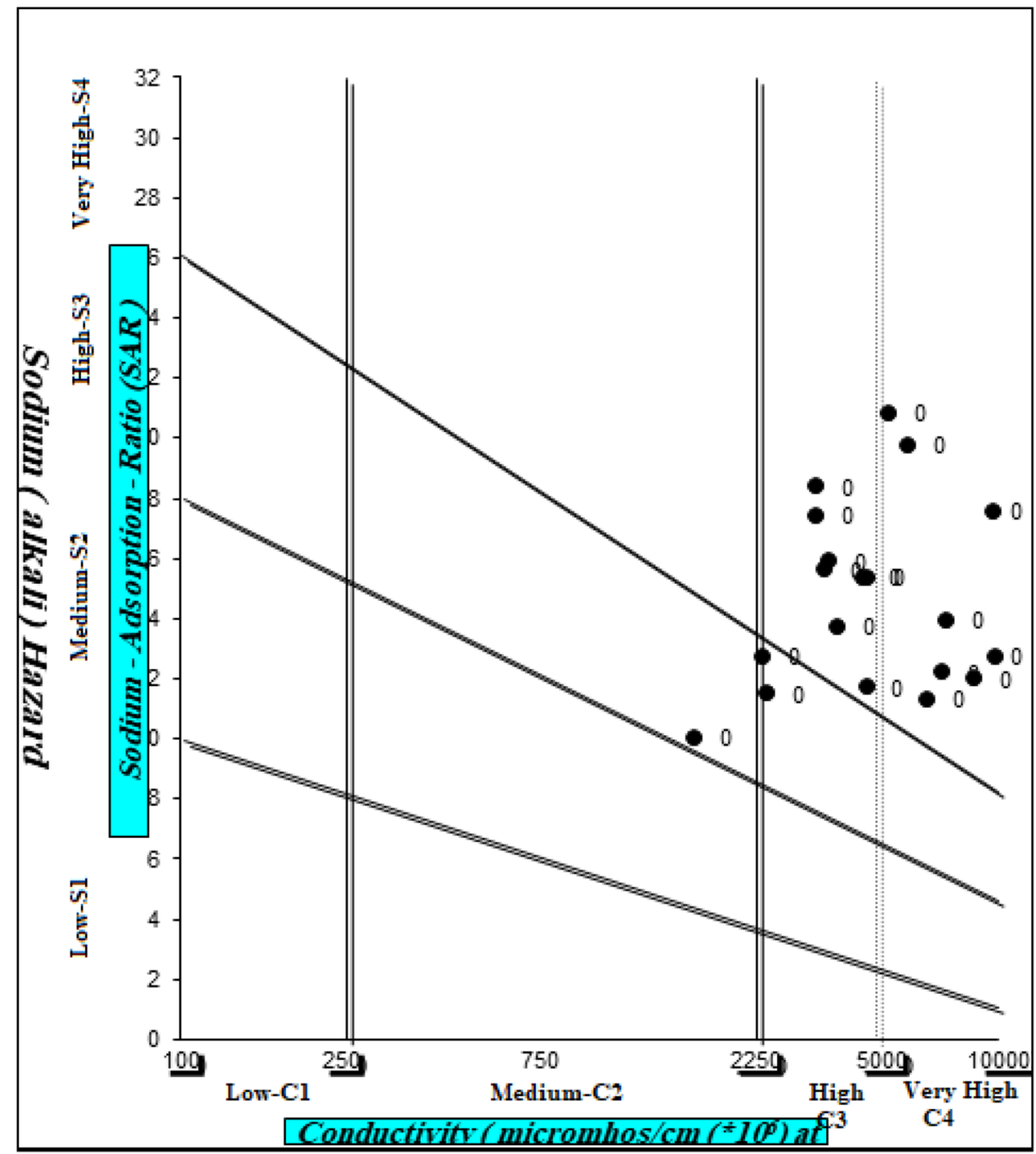

study can be related to the weathering of calcite and dolomite (Honarbakhsh et al. 2019), because the dissolution of limestone, gypsum and dolomite is the main source of this ion (Qishlaqi et al. 2017).

The Magnesium distribution in this plain is given in Fig. 11f, which shows that the higher amounts of Magnesium are located in the central and eastern regions, whereas the lower values of Magnesium are located in the western regions of the plain. Sources of magnesium ions are found in limestone aquifers.

The average concentration of Magnesium in the groundwater is $120.3 \mathrm{mg} / \mathrm{L}$ with a standard deviation of $90.08 \mathrm{mg} / \mathrm{L}$. The WHO (2017) has reported that a permissible concentration of this ion for drinking water is $30 \mathrm{mg} / \mathrm{L}$, which implies that the groundwater in the region is not appropriate with respect to the content of Magnesium.

Sodium is another characteristic studied in this study. The Sodium distribution of the groundwater in Sabzevar plain is shown in Fig. 11g. The higher value of Sodium is in the central areas, whereas its lower value is in the western areas of this plain. The statistical analysis results show that the average of Sodium in the groundwater of the plain is $1003 \mathrm{mg} / \mathrm{L}$ with a standard deviation of $396.9 \mathrm{mg} / \mathrm{L}$. The high concentration of this ion can be related to the weathering of salt domes and the process of evapotranspiration in Sabzevar plain (Honarbakhsh et al. 2019). The WHO (2017) has suggested a maximum concentration $200 \mathrm{mg} / \mathrm{L}$ of Sodium for drinking water. In this regard, the groundwater of this plain is almost five times more than the recommended limit, so it is not appropriate for use of drinking water.

In Fig. 11h, the Potassium content in the central and southern parts of Sabzevar plain are higher than in the western parts of this plain. The average concentration of Potassium is $79.12 \mathrm{mg} / \mathrm{L}$ with a standard deviation of $85.33 \mathrm{mg} / \mathrm{L}$. The maximum allowable amount of Potassium for drinking water is $12 \mathrm{mg} / \mathrm{L}$ as reported by the WHO (2017), which is much 
Fig. 11 Map of groundwater quality parameters in Sabzevar city

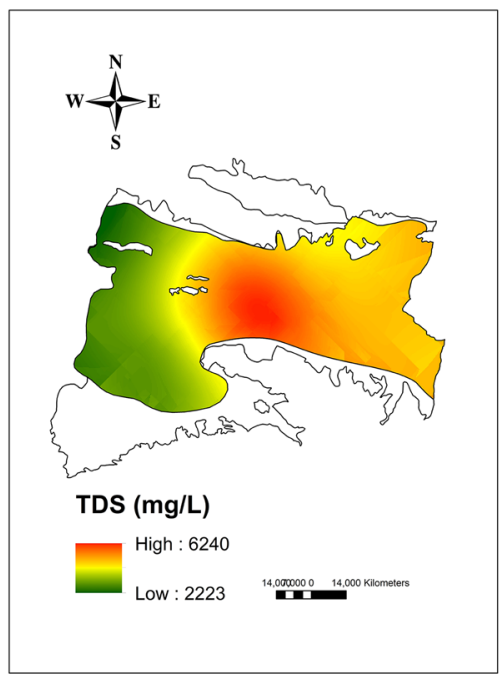

a

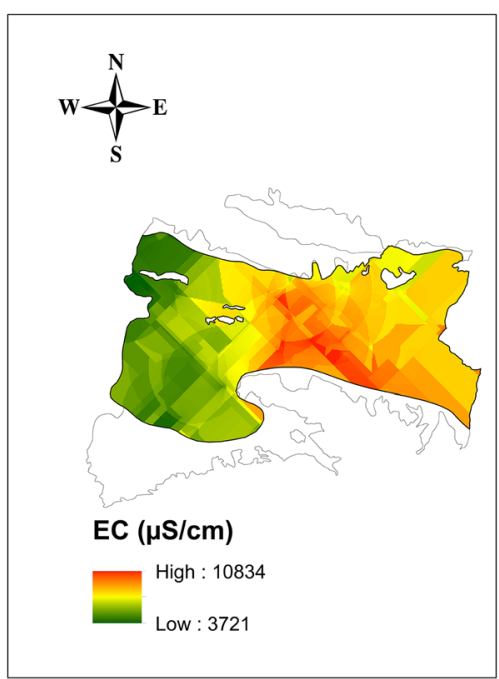

c

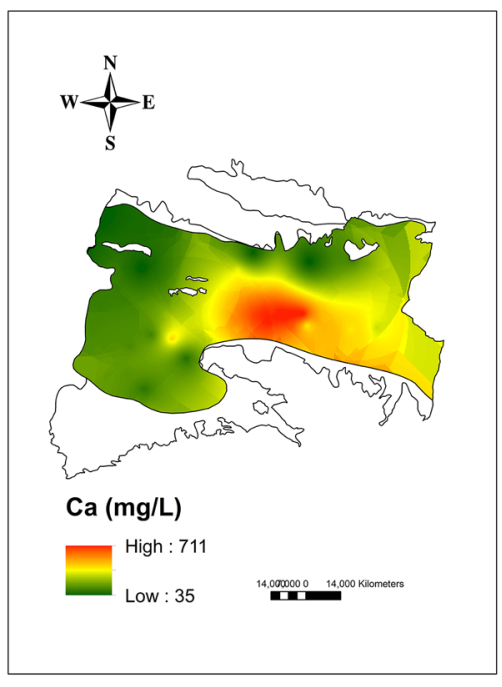

e

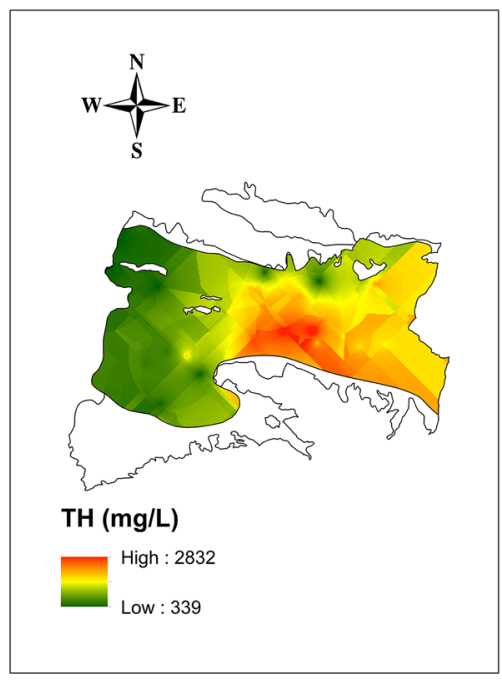

b

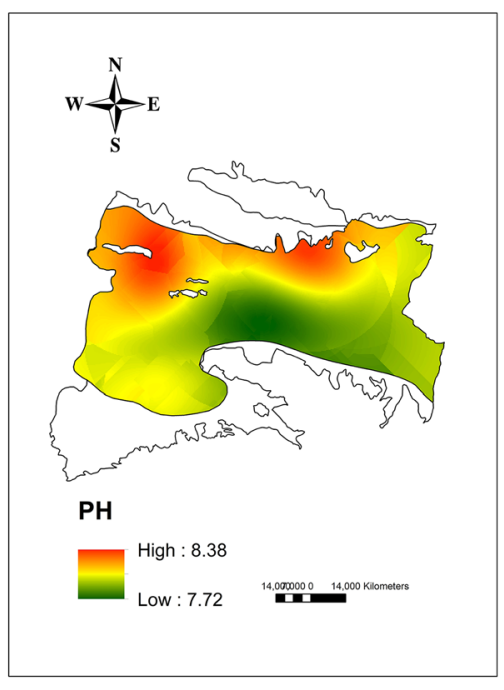

d

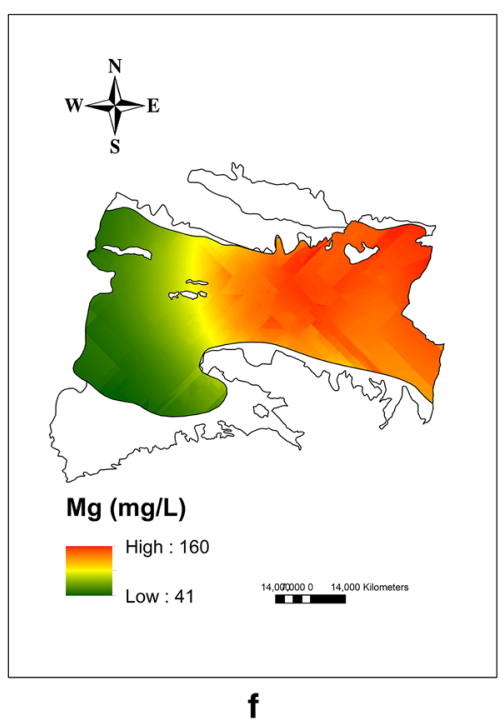


Fig. 11 (continued)

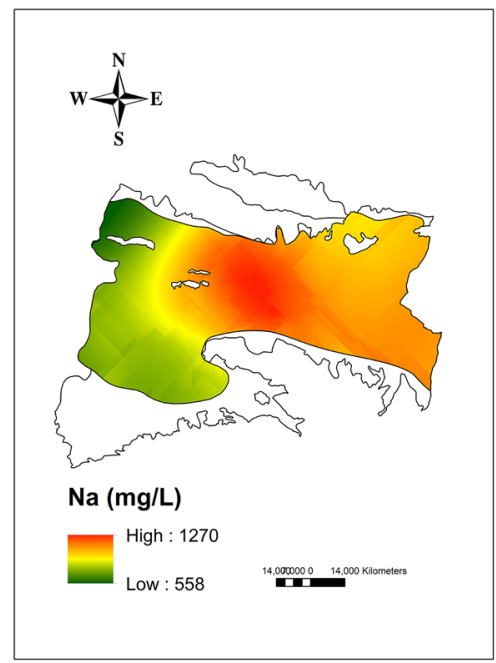

g

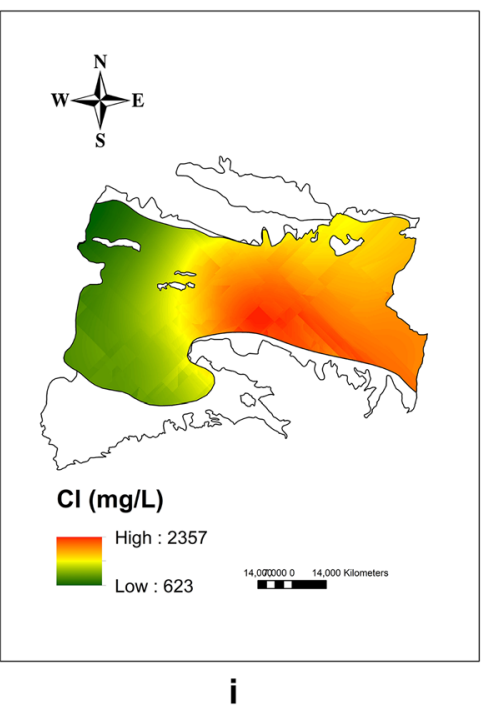

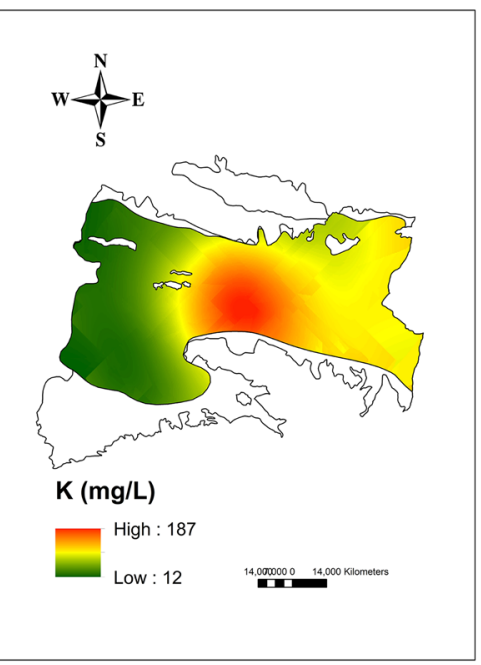

h

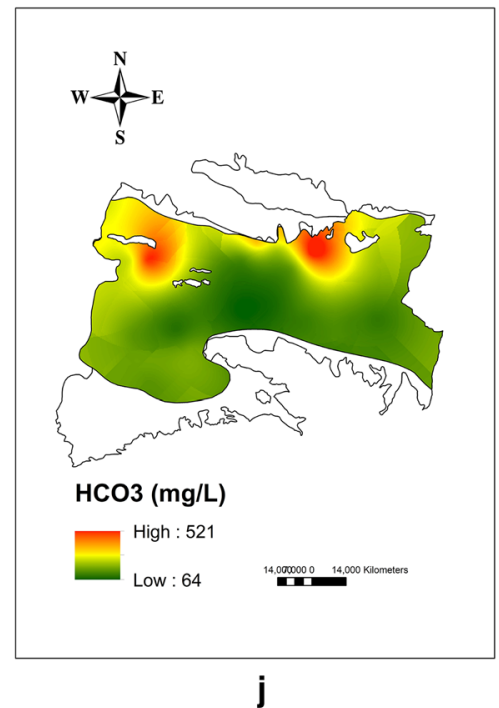

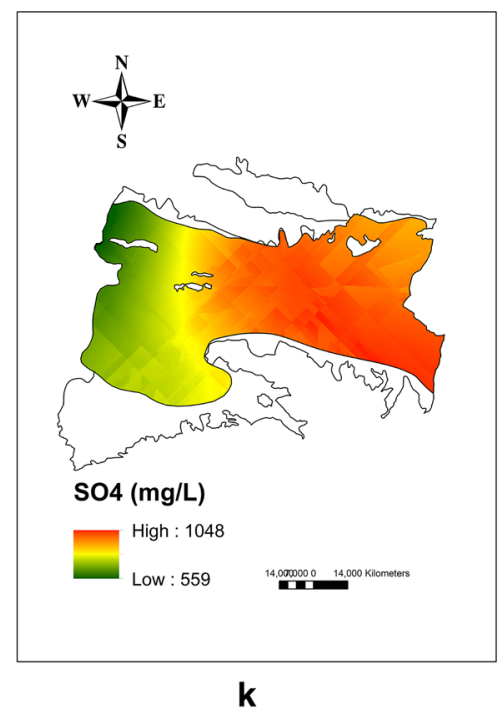


lower than the average value in this region, indicating that the groundwater in this plain is not usable for drinking water.

Figure 11i shows that the concentration values of Chlorine are higher in the central and southern regions but lower in the western regions of the study plain. The average of Chlorine is $1669.4 \mathrm{mg} / \mathrm{L}$ with a standard deviation of $1038.3 \mathrm{mg} / \mathrm{L}$, which is much higher than the maximum allowable amount $200 \mathrm{mg} / \mathrm{L}$ for drinking water, which inferred the high concentration of this ion is in such a way that the dissolution of gypsum and halite increased the chloride (Mallick et al. 2018). Therefore, the groundwater of Sabzevar plain is not suitable for the use of drinking water.

Figure $11 \mathrm{j}$ shows the distribution of Bicarbonate in the plain. Higher values of Bicarbonate are observed in the northern and northwestern regions of this plain in contrast with the lower values of Bicarbonate in the central and southern regions of this plain. The study showed that the average of bicarbonate in the groundwater of this plain is $197 \mathrm{mg} / \mathrm{L}$ with a standard deviation of $112.4 \mathrm{mg} / \mathrm{L}$. According to the standard of $200 \mathrm{mg} / \mathrm{L}$ for drinking water provided by the WHO, the groundwater quality in the study plain is acceptable with regards to this characteristic.

Finally, the distribution of Sulfate concentration of groundwater is shown in Fig. 11k, which reveals that its higher values are in the central and eastern parts of the plain, while the lower values are in the western parts. The average of Sulfate is $850.8 \mathrm{mg} / \mathrm{L}$ with a standard deviation of $327.5 \mathrm{mg} / \mathrm{L}$. The Sulfate level in the plain is much higher than the maximum allowable concentration $200 \mathrm{mg} / \mathrm{L}$ suggested by the WHO (2017), indicating that the groundwater in the plain is not appropriate for use. This result can be related to the discharge of industrial and agricultural effluents in the Sabzevar plain.

\section{Conclusion}

In the present study, 24 groundwater samples were collected for evaluating the groundwater quality from Sabzevar plain, which is located in a semi-arid region of Iran. Analyses were performed to evaluate physicochemical processes on water quality for drinking and agricultural uses. To evaluate the hydrochemical parameters, various maps of groundwater quality were generated based on GIS software. Pie and Schuler diagrams show that Chlorine is the predominant anion, while sodium cation is predominant in the study area. The Wilcox diagram shows that in the study area only $4.17 \%$ of the groundwater samples are in $\mathrm{C} 3 \mathrm{~S} 3$ class which have moderate salinity and alkalinity, and $8.33 \%$ of the samples are in $\mathrm{C} 4 \mathrm{~S} 3$ class and $87.5 \%$ are in C4S4 class which have salinity risk and a lot of alkali. Groundwater quality parameter maps in Sabzevar area show that groundwater quality is low in the central parts of the aquifer.
The results showed that most of the samples studied are not suitable for drinking water and agricultural uses based on the standard by the WHO (2017). In general, the groundwater in the study area indicated high alkalinity and salinity. The results of the present study imply the importance and necessity of implementing groundwater resources management to reduce pollution and prevent its spread in this area. Furthermore, based on the results of the Wilcox diagram, the large percentage of water samples is in the C4S4 class, which suggests that the groundwater would be used for agricultural purposes to salinity-resistant plants. Meanwhile, the results of Schuler diagram suggested that new methods for water treatment are needed for drinking purposes in this region.

Acknowledgements The authors would like to appreciate the academic support from the Water Engineering Department of Ferdowsi University. There is no conflict of interests, and all data used are available from the corresponding author on request.

Open Access This article is licensed under a Creative Commons Attribution 4.0 International License, which permits use, sharing, adaptation, distribution and reproduction in any medium or format, as long as you give appropriate credit to the original author(s) and the source, provide a link to the Creative Commons licence, and indicate if changes were made. The images or other third party material in this article are included in the article's Creative Commons licence, unless indicated otherwise in a credit line to the material. If material is not included in the article's Creative Commons licence and your intended use is not permitted by statutory regulation or exceeds the permitted use, you will need to obtain permission directly from the copyright holder. To view a copy of this licence, visit http://creativecommons.org/licenses/by/4.0/.

\section{References}

Ahn H, Chon H (1999) Assessment of groundwater contamination using geographic information systems. Environ Geochem Health 21(3):273-289

Association APH, Association AWW, Federation WPC, Federation WE (1915) Standard methods for the examination of water and wastewater, vol 2. American Public Health Association, Washington

Babiker IS, Mohamed MAA, Hiyama T (2007) Assessing groundwater quality using GIS. Water Resour Manag 21(4):699-715

Basem S, Sami Abu F, Alfred Y (2010) Assessment of groundwater quality in the gaza strip, palestine using GIS mapping. J Water Resour Prot. https://doi.org/10.4236/jwarp.2010.22011

Boyd CE (2019) Water quality: an introduction. Springer, Berlin

Cotruvo JA (2017) 2017 WHO guidelines for drinking water quality: first addendum to the fourth edition. J American Water Works Ass 109(7):44-51

Farid HU, Ahmad I, Anjum MN, Khan ZM, Iqbal MM, Shakoor A, Mubeen M (2019) Assessing seasonal and long-term changes in groundwater quality due to over-abstraction using geostatistical techniques. Environ Earth Sci 78(13):386

Godfrey S, Hailemicheal G, Serele C (2019) Climate resilient deep groundwater investigation and development in the Ogaden Jesoma sandstone aquifers of Somali Region, Ethiopia

Haghiabi AH, Nasrolahi AH, Parsaie A (2018) Water quality prediction using machine learning methods. Water Qual Res J 53(1):3-13 
Hill RA (1940) Geochemical patterns in Coachella Valley. Eos, Trans American Geophys Union 21(1):46-53

Hiscock KM, Lovett AA, Brainard JS, Parfitt JP (1995) Groundwater vulnerability assessment: two case studies using GIS methodology. Q J Eng Geol Hydrogeol 28(2):179-194

Honarbakhsh A, Azma A, Nikseresht F, Mousazadeh M, Eftekhari M, Ostovari Y (2019) Hydrochemical assessment and GIS-mapping of groundwater quality parameters in semi-arid regions. J Water Supply Res Technol AQUA 68(7):509-522

Hudak PF, Sanmanee S (2003) Spatial patterns of nitrate, chloride, sulfate, and fluoride concentrations in the woodbine aquifer of North-Central Texas. Environ Monit Assess 82(3):311-320

Hudak PF (2001) Water hardness and sodium trends in Texas aquifers. Environ Monit Assess 68(2):177-185

Jalees MI, Farooq MU, Anis M, Hussain G, Iqbal A, Saleem S (2021) Hydrochemistry modelling: evaluation of groundwater quality deterioration due to anthropogenic activities in Lahore, Pakistan. Environ Dev Sustain 23(3):3062-3076

Jeevanandam M, Kannan R, Srinivasalu S, Rammohan V (2007) Hydrogeochemistry and groundwater quality assessment of lower part of the Ponnaiyar River Basin, Cuddalore district, South India. Environ Monit Assess 132(1-3):263-274

Jeihouni M, Toomanian A, Alavipanah SK, Hamzeh S, Pilesjö P (2018) Long term groundwater balance and water quality monitoring in the eastern plains of Urmia Lake, Iran: a novel GIS based low cost approach. J Afr Earth Sc 147:11-19

Kheirandish M, Rahimi H, Kamaliardakani M, Salim R (2020) Obtaining the effect of sewage network on groundwater quality using MT3DMS code: case study on Bojnourd plain. Groundw Sustain Dev 11:100439

Lapworth DJ, Baran N, Stuart ME, Ward RS (2012) Emerging organic contaminants in groundwater: a review of sources, fate and occurrence. Environ Pollut 163:287-303

Longe EO, Balogun MR (2010) Groundwater quality assessment near a municipal landfill, Lagos, Nigeria. Res J Appl Sci Eng Technol 2(1):39-44

Magesh NS, Krishnakumar S, Chandrasekar N, Soundranayagam JP (2013) Groundwater quality assessment using WQI and GIS techniques, Dindigul district, Tamil Nadu, India. Arab J Geosci 6(11):4179-4189

Maghfouri S, Rastad E, Mousivand F, Choulet F, Ye L (2017) Geological and geochemical constraints on the Cheshmeh-Frezi volcanogenic stratiform manganese deposit, southwest Sabzevar basin, Iran. Ore Geol Rev 89:96-113

Mallick J, Singh CK, AlMesfer MK, Kumar A, Khan RA, Islam S, Rahman A (2018) Hydro-geochemical assessment of groundwater quality in Aseer Region, Saudi Arabia. Water 10(12):1847

Mansour-Bahmani A, Haghiabi AH, Shamsi Z, Parsaie A (2020) Predictive modeling the discharge of urban wastewater using artificial intelligent models (case study: Kerman city). Model Earth Syst Environ 7:1-9
Meshesha TW, Wang J, Melaku ND, McClain CN (2021) Modelling groundwater quality of the Athabasca River Basin in the subarctic region using a modified SWAT model. Sci Rep 11(1):1-12

Mishra JK, Joshi MD, Devi R (1994) Technical Note Study of desertification process in Aravalli environment using remote ensing techniques. Remote Sens 15(1):87-94

Nas B, Berktay A (2010) Groundwater quality mapping in urban groundwater using GIS. Environ Monit Assess 160(1-4):215-227

Osborn GH, Johns H (1951) The rapid determination of sodium and potassium in rocks and minerals by flame photometry. Analyst 76(904):410-415

Parsaie A, Haghiabi AH (2016) Numerical modeling of effect of dead zones on concentration profile of pollution in rivers. Water Sci Technol Water Supply 17(3):825-834

Patil VT, Patil PR (2011) Groundwater quality of open wells and tube wells around Amalner town of Jalgaon district, Maharashtra, India. J Chem 8(1):53-58

Piper AM (1944) A graphic procedure in the geochemical interpretation of water-analyses. Eos, Trans American Geophy Union 25(6):914-928

Qishlaqi A, Kordian S, Parsaie A (2017) Hydrochemical evaluation of river water quality - a case study. Appl Water Sci 7(5):2337-2342

Richards LA (1954) Diagnosis and improvement of saline and alkali soils, vol 78. LWW, Philadelphia

Rostami AA, Isazadeh M, Shahabi M, Nozari H (2019) Evaluation of geostatistical techniques and their hybrid in modelling of groundwater quality index in the Marand Plain in Iran. Environ Sci Pollut Res 26(34):34993-35009

Selvam S, Manimaran G, Sivasubramanian P (2013) Hydrochemical characteristics and GIS-based assessment of groundwater quality in the coastal aquifers of Tuticorin corporation, Tamilnadu, India. Appl Water Sci 3(1):145-159

Stamatis G, Alexakis D, Gamvroula D, Migiros G (2011) Groundwater quality assessment in Oropos-Kalamos basin, Attica, Greece. Environ Earth Sci 64(4):973-988

Xie H, Yao G, Liu G (2015) Spatial evaluation of the ecological importance based on GIS for environmental management: a case study in Xingguo county of China. Ecol Ind 51:3-12

Publisher's Note Springer Nature remains neutral with regard to jurisdictional claims in published maps and institutional affiliations. 